\title{
KENDALA PENCIPTAAN KARYA TARI OLEH MAHASISWA
}

\author{
Oleh: \\ Ni Nyoman Seriati \\ FBS, UNIVERSITAS NEGERI YOGYAKARTA \\ Email:ninyoman_seriati@yahoo.com \\ HP.08156801791
}

\begin{abstract}
Abstrak
Penelitian ini bertujuan untuk mengidentifikasikan kesulitan mahasiswa dalam menciptakan karya tari pada mata kuliah Koreografi III mahasiswa Jurusan Pendidikan Seni Tari FBS, UNY.

Untuk menemukan tingkat kesulitan yang dialami mahasiswa digunakan pendekatan Dikriptip Kuantitatip, sujek penelitian mahasiswa yang mengambil mata kuliah koreografi III pada semester ganjil tahun ajaran 2013/1014 berjumlah 24 orang. Teknik pengumpulan data dengan menggunakan kuesioner dan pengamatan. Teknik analisis data menggunakan statistik diskriptif. Penelitian ini dilaksanakan di Jurusan Pendidikan Seni Tari ,FBS, UNY khususnya untuk mahasiswa yang menempuh kuliah pada semester 9. Hasil penelitian menunjukkan sebagai berikut mahasiswa yang mengalami kesulitan dalam penciptaan karya tari pada mata kuliah koreografi III terletak pada elemen -elemen koreografi diantaranya: penentuan cerita, tema, busana, gerak, dan musik. Adapun tingkat kesulitan dari kelima elemen tersebut cerita 2,08\%, tema 2,22 \%, busana 2,26 \%, gerak 2,46 \%, dan musik 3,10 \%. Dari uraian tersebut dapat dilihat bahwa tingkat kesulitan yang paling tinggi terletak pada penentuan cerita.
\end{abstract}

Kata Kunci: Kesulitan, mencipta

\section{THE DIFFICULTIES FACED BY STUDENTS OF DANCE EDUCATION DEPARTMENT OF FBS UNY IN CREATING DANCES}

\begin{abstract}
The purpose of the study is to identify the difficulties students face when creating dances in Coreography III Course at Dance Education Department of FBS UNY.

Descroptive qualitative approach was used to find the difficulties faced by 23 students who took Coreography III course in the academic year of 2013/2014. The data collection technique was conducted by using questioner and observation method. The data analysis technique used in this research was descriptive statistic method. The research was conducted in Dance Education Department of FBS UNY, especially on the 9th semester students. The results shows that students found difficulties in terms of some elements in coreography such as determining the story board (faced by $2.08 \%$ of students), themes (faced by $2.22 \%$ of students) , costumes (faced by $2.26 \%$ of students), movements (faced by $2.46 \%$ of students) , and music (faced by $3.10 \%$ of students). Thus, it can be seen that the highest level of difficulty faced by students is in the form of determining the story board.
\end{abstract}

Keywords: difficulties, creating 


\section{A. PENDAHULUAN}

Koreografi menjadi disiplin ilmu tari, baik secara teoretis maupun praktis. Secara teoretis, koreografi mempelajari dasar-dasar pengetahuan atau metode penataan tari yang meliputi konsep, teori, maupun prinsip-prinsip yang telah dikemukakan oleh para koreografer maupun ilmuan di bidang tari. Sementara secara praktis konsep koreografi dipahami sebagai praktik atau keterampilan, keahlian dalam mencipta dan sering juga disebut dengan sebutan seni menata gerak-gerak tari. Dewasa ini kenyataan di lapangan koreografi mengajarkan kombinasi teori dan praktik, yaitu memberikan metode, pengetahuan, dan praktik penataan tari (Hadi, 2011:8). Jurusan Pendidikan Seni Tari, FBS, UNY yang mencetak calon guru tari mempersiapkan lulusannya untuk menjadi guru yang memiliki kompetensi dalam bidangnya, tidak hanya mampu menari saja, tetapi juga mampu membuat (menciptakan) karya tari sendiri. Dengan demikian, guru tari mampu mengekspresikan diri melalui pengalaman menari dan mengkreasi tari (menyusun tari/koreografi) sebagai wujud pengembangan bakat seni (Jacqueline, 1985:7).

Oleh karenanya, pada kurikulum pendidikan seni tari tercantum salah satu Matakuliah Koreografi III yang ditempuh pada semester tujuh. Matakuliah ini bertujuan untuk memberikan bekal kepada mahasiswa selain menjadi guru tari juga mampu untuk menciptakan tari sendiri (koreografer). Sifat dari matakuliah ini adalah praktik, yaitu mahasiswa menghasilkan satu karya tari dalam bentuk kelompok yang dikerjakan selama satu semester. Sebagai koreografer pemula maka dalam pelaksanaannya satu karya dikerjakan oleh dua mahasiswa. Pada akhir semester mahasiswa wajib menyajikan/mementaskan hasil karyanya di atas panggung secara total.

Untuk mencapai karya tari yang baik tidaklah mudah. Meri (1975: 2 ) mengibaratkan koreografi sebagai sebuah lukisan/gambar yang hidup dan menarik. Oleh karenanya sebelum melukis dibutuhkan pemahaman terhadap pembentuk lukisan tersebut. Adapun pembentuk dari koreografi berupa elemen-elemen yang terdiri atas gerak, tema, desain lantai, desain atas, desain musik, cerita, desain dramatik, dinamika, tata rias dan busana, properti, panggung, lighting, serta komposisi kelompok. Elemen tersebut secara tersirat semuanya harus dirancang dan disajikan dalam karya koreografi mulai dari menentukan cerita, tema sampai dengan menuangkan ke dalam gerak serta menyajikan di atas panggung. Begitu banyak elemen yang harus disatukan. Dengan demikian, koreografi dikatakan sebagai kegiatan yang berkaitan dengan kreativitas. Sebagai calon koreografer harus kreatif membekali diri dengan memperkaya teknik berbagai macam gerak tari. 
Berkaitan dengan hal tersebut, Hadi (2003:65-74) menyatakan proses kreasi melalui tiga tahap, yaitu eksplorasi, improvisasi, dan pembentukan. Eksplorasi dimaksudkan sebagai kegiatan berpikir, berimajinasi, merasakan, dan merespon terhadap peristiwa/cerita untuk mendapatkan ide. Improvisasi dimaksudkan sebagai penemuan gerak secara spontan atau tahap mencoba-coba bagi koreografer untuk mencari materi gerak. Pembentukan proses perwujudan suatu struktur atau mewujudkan prinsip-prinsip bentuk diantaranya kesatuan, variasi, repetisi, transisi, rangkaian, perbandingan, dan klimaks untuk menjadi satu kesatuan. Melihat dari kompleksnya persiapan yang harus dilakukan oleh mahasiswa maka dibutuhkan kesiapan fisik dan non fisik. Fisik yang dimaksud adalah kemampuan teknik kepenarian dan kekuatan kreavitas mahasiswa dalam mengembangkan elemen-elemen tersebut di atas, sedangkan non fisik adalah sarana yang mendukung proses kreatif diantaranya tempat dan pendanaan.

Begitu kompleksnya dalam penataan koreografi tari, tidak jarang mahasiswa mengalami kesulitan dalam mewujudkan karya tersebut. Peserta didik yang mengalami kesulitan belajar adalah peserta didik yang memiliki intelegensi normal, tetapi menunjukkan satu atau beberapa kekurangan yang penting dalam proses belajar, baik dalam persepsi, ingatan, perhatian, ataupun dalam fungsi motoriknya. Dengan kata lain, peserta didik dikatakan mengalami kesulitan belajar bila prestasi belajar yang dicapai tidak sesuai dengan kapasitas intelegensinya. Dengan demikian, kesulitan belajar tidak hanya dialami oleh peserta didik yang intelegensinya rendah. Dijelaskan pula bahwa ada dua faktor yang mempengaruhi kesulitan belajar, yaitu faktor dari dalam dan faktor dari luar. Faktor dari dalam meliputi intelektual, afeksi, perasaan, percaya diri, motivasi, kematangan untuk belajar, usia, jenis kelamin, kebiasaan belajar, kemampuan mengingat, dan kemampuan pengindraan, seperti melihat, mendengarkan, dan merasakan. Faktor dari luar berkaitan dengan kondisi proses pembelajaran yang meliputi guru, kualitas pembelajaran, instrumen/fasilitas pembelajaran baik, dan lingkungan. Di sini guru dituntut memiliki kemampuan mengenali peserta didik yang mengalami kesulitan belajar dan mencari faktor penyebab kesulin belajar tersebut (Sugihartono, 2012:148). Selanjutnya diharapkan guru dapat menentukan teknik untuk membantu mengatasi kesulitan belajar yang dialami oleh peserta didik.

Pada mata kuliah koreografi III mahasiswa lebih pada menerapkan teori penciptaan (koreografi) atau elemen-elemen penciptaaan tari yang terdiri atas ide garapan (cerita), tema, gerak tari, rias dan busana, setting, dramatik, dinamika, desain lantai, tata lampu, musik, properti, dan kebutuhan yang lainnya. Mengingat keberhasilan suatu koreografi sangat tergantung pada hal tersebut di atas bagaimana inspirasi artistik koreografer, penguasaan 
perbendaharaan gerak, pemahaman tentang wujud dan struktur tarinya menjadi pertimbangan yang utama. Elemen tersebut saling berkaitan satu dengan yang lainnya untuk mewujudkan bentuk dalam karya tari. Oleh karenanya, Primadi (2000:24) membagi proses kreasi dalam koreografi menjadi dua. Pertama, tahap penentuan ide dan kedua, tahap pelaksana. Kedua tahap tersebut dikelompokkan kedalam 8 tingkatan, tahap untuk menentukan ide berada pada tingkat 1 -5 dan tingkat $6-8$ pelaksanaan kreasi dan hasil kreasi. Betapa pentingnya penentuan dan kejelasan ide dalam penciptaan karya karena ibarat suatu bangunan bahwa harus dirancang/dilandasi dengan dasar atau pondasi yang kuat. Kejelasan ide di sini dimaksudkan penentuan tema garapan dapat berupa literer maupun non literer. Apabila cerita dan tema sudah diyakini langkah selanjutnya adalah penyusunan konsep yaitu menentukan tipe dan mode penyajian garapan tari.Setelah konsep-konsep tersebut dianggap matang baru selanjutnya dilakukan kegiatan berkreasinya salah satunya adalah pengembangan gerak (Hidayat, 2011:90).

Berdasarkan latar belakang masalah di atas penelitianini difokuskan pada Idetifikasi Kesulitan Dalam Menciptakan Karya Tari pada Mata Kuliah Koreografi III Mahasiswa Jurusan Pendidikan Seni Tari, FBS, UNY. Penelitian ini bertujuan untuk menemukan dan mengungkap kesulitan-kesulitan yang dialami oleh mahasiswa Pendidikan Seni Tari dalam menciptakan karya tari pada mata kuliah Koreografi III, serta mengungkap persentase tingkat kesulitan yang paling tinggi dari elemen-elemen koreografi.

\section{B. METODE}

Penelitian ini adalah jenis penelitian kuantitatif diskriptif maksudnya mendiskripsikan sasaran dengan menggunakan data berupa angka-angka (Sugiyono, 2012: 13). Diskriptif maksudnya menjelaskan fenomena-fenomena yang terjadi pada objek penelitian ini yaitu mendiskripsikan tentang kesulitan-kesulitan yang dialami mahasiswa Jurusan Pendidikan Seni Tari dalam penciptaan karya tari pada matakuliah Koreografi III.

Subyek dalam penelitian ini adalah mahasiswa angkatan tahun 2010 yang mengambil matakuliah koreografi III pada semester ganjil tahun ajaran 2013/2014. Jumlah mahasiswa yang mengambil mata kuliah ini sebanyak 74 orang, dari jumlah mahasiswa tersebut ada 37 karya tari karena satu karya tari disusun oleh dua orang mahasiswa. Masing-masing karya tari diwakili oleh satu orang mahasiswa, ini diharapkan dapat mewakili dari jumlah responden yang ada. Ada 30 angket yang disebarkan, dari jumlah tersebut ada 24 angket yang kembali.

Teknik pengumpulan data dilakukan dengan metode kuesioner dan pengamatan. Untuk mengumpulkan data tentang kesulitan dalam menciptakan karya tari dilakuakan 
dengan menggunakan kuesioner. Sedangkan pengamatan dilakukan dengan Observasi berperanserta (Participant Observation) terhadap kegiatan yang dilakukan oleh responden (Sugiyono, 2012: 204) selama proses penciptaan karya tari.

Data yang didapatkan melalui angketselanjutnya dianalisis dengan menggunakan Statistik diskriptif. Data dianalisis dengan cara mendiskripsikan atau menggambarkan data yang telah terkumpul sebagaimana adanya tanpa bermaksud membuat kesimpulan yang berlaku untuk umum. Penyajian data dilakukan dalam bentuk tabel (Sugiyono, 2011: 207 208).

\section{HASIL PENELITIAN DAN PEMBAHASAN}

Hasil penelitian ini menunjukkan dari 14 elemen yang ada dalam koreografi, bahwa ada lima elemen yang dirasa sulit oleh mahasiswa di dalam penciptaan koreografi III. Adapun kelima elemen tersebut adalah: cerita, tema, gerak, busana, dan musik. Dari kelima elemen tersebut tingkat kesulitannya berbeda-beda. Untuk lebih jelasnya lihat tabel di bawah ini.

Tabel 1. Penentuan Cerita dalam penciptaan karya tari

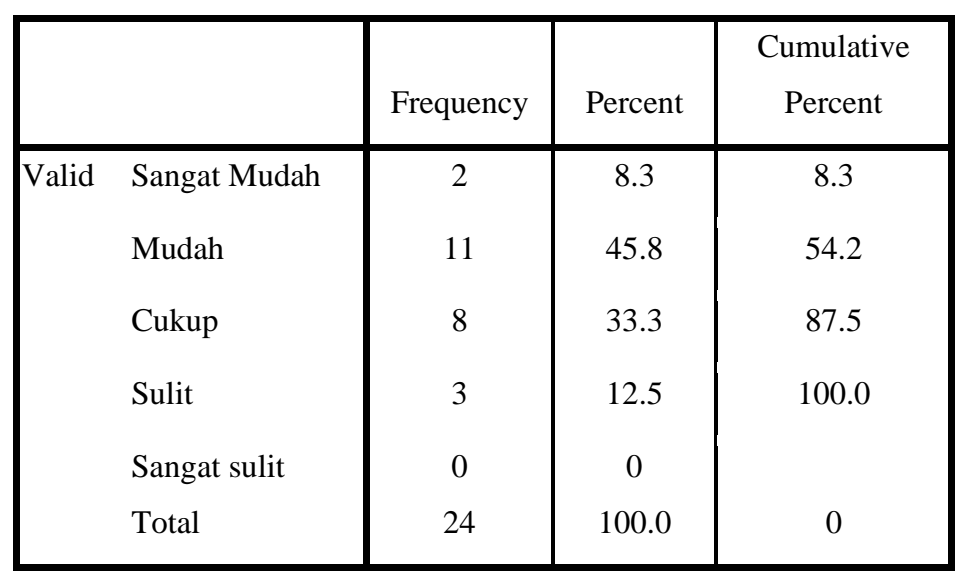

Tabel 2. Penentuan tema dalam penciptaan karya tari

\begin{tabular}{|ll|c|c|c|}
\hline & Frequency & Percent & Cumulative Percent \\
\hline \multirow{2}{*}{ Valid } & Sangat Mudah & 0 & 0 & 0 \\
& Mudah & 6 & 25.0 & 25.0 \\
& Cukup & 6 & 25.0 & 50.0 \\
Sulit & 9 & 37.5 & 87.5 \\
Sangat Sulit & 3 & 12.5 & 100.0 \\
Total & 24 & 100.0 & \\
& & & & \\
\hline
\end{tabular}


Tabel 3. Pengembangan gerak dalam penciptaan karya tari

\begin{tabular}{|c|c|c|c|c|}
\hline & & Frequency & Percent & $\begin{array}{c}\text { Cumulative } \\
\text { Percent }\end{array}$ \\
\hline Valid & $\begin{array}{l}\text { Sangat Mudah } \\
\text { Mudah } \\
\text { Cukup } \\
\text { Sulit } \\
\text { Sangat Sulit } \\
\text { Total }\end{array}$ & $\begin{array}{l}0 \\
9 \\
10 \\
4 \\
1 \\
24\end{array}$ & $\begin{array}{c}0 \\
37.5 \\
41.7 \\
16.7 \\
4.2 \\
100.0\end{array}$ & $\begin{array}{c}0 \\
37.5 \\
79.2 \\
95.8 \\
100.0\end{array}$ \\
\hline
\end{tabular}

Tabel 4. Perancangan Tata Busana

\begin{tabular}{|l|r|r|r|}
\hline & Frequency & Percent & \multicolumn{2}{|c|}{\begin{tabular}{c} 
Percent \\
\hline Valid
\end{tabular} Sangat Mudah } & 1 & 4.2 & 4.2 \\
& 7 & 29.2 & 33.3 \\
Mudah & 6 & 25.0 & 58.3 \\
Cukup & 7 & 29.2 & 87.5 \\
Sulit & 3 & 12.5 & 100.0 \\
Sangat Sulit & 24 & 100.0 & \\
\hline Total & & & \\
\hline
\end{tabular}

Tabel 5. Menentukan Musik

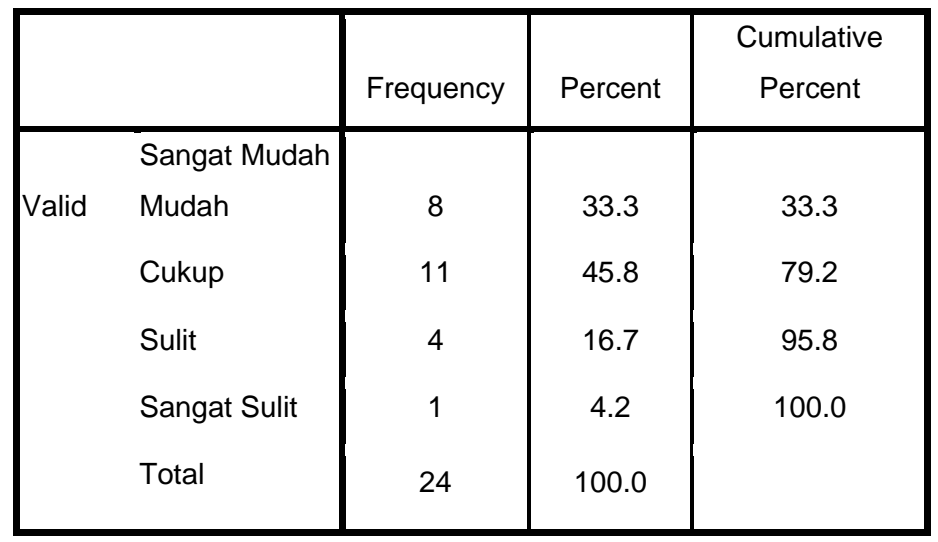

Tabel 6. Kategori Identifikasi Kesulitan Penciptaan Karya Tari 


\begin{tabular}{|l|c|c|c|c|}
\hline & Frequency & Percent & Valid Percent & $\begin{array}{c}\text { Cumulative } \\
\text { Percent }\end{array}$ \\
\hline Vali Cukup & 11 & 45.8 & 45.8 & 45.8 \\
d Sulit & 12 & 50.0 & 50.0 & 95.8 \\
$\quad$ Sangat Sulit & 1 & 4.2 & 4.2 & 100.0 \\
$\quad$ Total & 24 & 100.0 & 100.0 & \\
\hline
\end{tabular}

Tabel 7. Tingkat kesulitan yang dialami mahasiswa

\begin{tabular}{|l|r|c|r|c|}
\hline Komponen & Rerata & $\begin{array}{l}\text { Jumlah } \\
\text { instrumen }\end{array}$ & Total skor & Rangking \\
\hline TEMA & 11,08 & 5 & 2,22 & IV \\
\hline GERAK & 7,38 & 3 & 2,46 & II \\
\hline BUSANA & 6,79 & 3 & 2,26 & III \\
\hline MUSIK & 12,38 & 4 & 3,10 & I \\
\hline CERITA & 10,39 & 5 & 2,08 & $\mathrm{~V}$ \\
\hline
\end{tabular}

Berdasarkan tabel 7. di atas terlihat bahwa 50,0\% mahasiswa kesulitan dalam menciptakan karya tari dan 4,2\% menyatakan sangat sulit. Data tersebut menunjukkan bahwa mahasiswa mengalami kesulitan dalam menciptakan karya tari. Sementara tabel 2. menunjukkan bahwa tingkat kesulitan yang dialami oleh mahasiswa, yaitu tingkat kesulitan paling tinggi terletak pada cerita 2,08\%, tingkat kesulitan berikutnya terletak pada tema 2,22\%, sedangkan busana ada pada tingkat ketiga 2,26\%, pengembangan gerak diperoleh data 2,46\% ini menunjukkan bahwa pada pengembangan gerak mahasiswa tidak mengalami kesulitan, dan musik berada pada peringkat pertama diperoleh data 3,10\% menunjukkan pada pembuatan musik mahasiswa tidak mengalami kesulitan.

Dari data tersebut di atas menunjukkan bahwa mahasiswa mengalami kesulitan dalam menciptakan karya tari, ini diasumsikan mahasiswa belum memiliki pengalaman yang memadai dalam menciptakan karya tari, baik secara teori maupun praktik. Adapun tingkat kesulitan yang dialami oleh mahasiswa dalam menciptakan karya tari kelompok terletak pada lima elemen koreografi, yaitu cerita, tema, tata busana, gerak, dan musik. Berikut ini akan diuraikan satu persatu sesuai dengan tingkat kesulitan yang dialami mahasiswa sebagai berikut: 
1. Cerita adalah salah satu elemen pokok pada penggarapan karya tari, karena cerita merupakan sumber ide/inspirasi untuk mewujudkan bentuk dari karya tari tersebut. Dari data di atas menunjukkan bahwa tingkat kesulitan tertinggi ada pada pemilihan cerita. Dalam penyajiannya cerita dapat disajikan secara naratif guna menampakkan kejelasan dari cerita yang dibawakan, namun demikian ada juga yang menyajikan menekankan pada inti dari cerita tersebut dalam artian tidak menjalankan cerita secara naratif. Hidayat ( 2011:93) menyatakan bentuk merupakan jalinan yang saling berkaitan antara bagian satu dengan yang lainnya sesuai dengan cerita yang disajikan. Sumber cerita dapat diambil dari berbagai peristiwa seperti : peristiwa sosial yang sedang terjadi di masyarakat, peristiwa ritual, kondisi alam, sejarah, legenda, cerita panji, epos Mahabarata, Ramayana dan masih banyak yang lainnya. Dari cerita tersebut mahasiswa diberi kebebasan untuk memilihnya sesuai dengan kemampuan dan kepekaannya dalam mengimajinasikan peristiwa tersebut.

Walaupun objek tentang cerita cukup banyak berkembang di masyarakat seperti yang diuraikan di atas, namun mahasiswa masih kesulitan untuk memilih cerita. Dari data dan pengamatan dilapangan ditemukan bahwa mahasiswa kurang memahami cerita-cerita seperti cerita tradisi/foklor, epos Mahabarata, Ramayana, Panji, sejarah, dan yang lainnya. Mahasiswa sulit untuk mendapatkan jenis buku-buku seperti yang telah diuraikan di atas. Ini perlu didukung oleh lembaga untuk menyiapkan referensi yang cukup diperpustakaan baik jurusan maupun fakultas sehingga memudahkan bagi mahasiswa untuk mencari referensi.

2. Tema adalah pokok permasalahan dalam penggarapan karya tari, oleh karenanya tema membutuhkan pertimbangan yang serius karena tema berdapak pada pemunculan dramatik pada karya tari. Dari data yang didapatkan melalui angket bahwa 2,22\% mahasiswa mengalami kesulitan dalam menentukan tema pada karya tarinya. Demikian juga hasil pengamatan dilapangan bahwa mahasiswa masih sulit untuk menentukan tema.

Berkaitan dengan hal tersebut seorang ahli tari menyatakan sebelum tema diangkat menjadi karya tari ada beberapa persyaratan yang harus dipenuhi yaitu: 1) Keyakinan koreografer terhadap tema yang dipilih, 2) Apakah tema tersebut dapat ditarikan,3) Apakah efek sesaat dari tema terhadap penonton menguntungkan, 4) Persiapan teknik tari baik dari baik dari koreografer maupun penari, 5) Kesiapan sarana dan prasarana (Meri, 1978:32). Dari kelima persyaratan tersebut menunjukkan bahwa tema menjadi pokok sentra dalam penggarapan karya tari. Guna mengantisipasi hal tersebut perlu dicari solusinya dalam proses pembelajaran perlu ditingkatkan materi-materi ajar dengan mengkaji tentang bagaimana menentukan tema dari sebuah cerita. 
3. Di dalam tariTata busana, di dalam tari busana berfungsi sebagai penutup badan, disamping itu busana juga dapat menunjukkan peran dan karakter yang dibawakan/dimainkan oleh penari. Karakter yang dimainkan oleh seorang tokoh dapat dilihat lewat warna dan desain kostum yang dikenakan.

Dari data tersebut di atas menunjukkan beberapa dari mahasiswa mengalami kesulitan yaitu 2.26\% dalam perancangan busana. Dari pengamatan dilapangan menunjukkan bahwa pemahaman mahasiswa terhadap karakter dari tokoh terutama pada cerita-cerita tardisi masih kurang. Dengan demikian halnya pemahaman terhadap warna sangat penting dalam perancangan kostum karena warna adalah simbol dari karakter yang dibawakan. Untuk mengatasi hal tersebut pada matakuliah yang berkaitan dengan busana tari silabinya perlu dicantumkan pemahaman tentang desain busana tradisi dan dan pemahaman tentang warna karena berkaitan dengan karakter dari tokoh yang ada.

4. Secara umum tari diartikan sebagai seni gerak, oleh karenanya gerak dalam penciptaan karya tari adalah gerak dalam pengertian estetik artinya gerak dihadirkan sebagai elemen untuk mewujudkan sebuah karya (Hidayat, 2011: 26). Pemilihan gerak menjadi sangat penting karena setiap gerak memiliki fungsi komunikatif yang berbeda-beda, oleh karenya tidak hanya menekankan pada merangkai gerak saja akan tetapi bagaimana gerak yang disusun dapat dipahami oleh penonton sesuai dengan tema yang dibawakan. Ditegaskan pula oleh Jequiline Smith dalam Ben Suharto ( 1985:16) bahwa gerak merupakan bahasa komunikasi yang luas dan variasi dari berbagai unsur-unsur dan terdiri dari beribu-ribu kata gerak.

Dari data di atas menunjukkan bahwa gerak berada pada urutan ke 4 dengan porsentase 2,46\% mendapatkan nilai yang tinggi, ini menunjukkan tingkat kesulirtan yang dialami oleh mahasiswa rendah. Dilihat dari sisi kesiapan mahasiswa dalam mengembangkan kreativitas gerak cukup bagus. Dukungan mata kuliah praktik tari cukup memberi andil dalam pengembangan kreativitas gerak, karena mata kuliah koreografi III ini berada di semester 7. Secara otomatis dari semester 1 -6 mahasiswa sudah menempuh berbagai macam gaya tari dari berbagai daerah yang ada di Indonesia. Kurikulum yang ada di Jurusan Pendidikan Seni Tari mencantumkan mata kuliah Tari Nusantara, tari Gaya Yogyakarta, Tari gaya Surakarta. Matakuliah tersebut cukup memberikan bekal bagi mahasiswa dalam berkreasi. Berdasarkan pengamatan di lapangan mahasiswa dapat dengan mudah dalam mengkreasikan gerak demikian juga dengan kesiapan yang berkaitan dengan teknik gerak.

5. Musik adalah partner dari tari yang membantu untuk mengiringi tari serta fungsinya membantu untuk mewujudkan suasana. Disamping itu musik sebagai partner tari membantu untuk mewujudkan tempo dan ritme pada setiap gerak. Sebagai penari yang propesional dituntut memiliki kepekaan terhadap rasa musikal dengan demikian kualitas kepenariannya 
akan tampil dengan maksimal. Aspek musikal mempunyai kesatuan bentuk dan isi, walaupun sebagai penunjang, kehadirannya tidak dapat diabaikan karena membentuk keutuhan rasa tari yang di sajikan. Pada dasarnya tari dan musik berasal dari sumber yang sama yaitu dorongan naluri ritmis manusia.

Musik dalam koreografi bersifat fungsional sebagi berikut: 1) musik sebagai iringan ritmis gerak tarinya, 2) musik sebagai ilustrasi pendukung suasana tarinya, 3) musik sebagai penegasan gerak dan pemberi suasana (Hadi, 2003:52). Dari data di atas terlihat bahwa musik berada pada urutan pertama dengan persentase 3,10\% mendapatkan nilai yang tinggi. Ini menunjukkan tingkat kesulitan yang dialami oleh mahasiswa rendah. Melihat hasil angket tersebut dimungkinkan ada dua faktor yang mempengaruhi. Pertama dalam penyusunan gerak para mahasiswa dalam menciptakan karya tari sudah mempertimbangkan tempo gerak, yaitu cepat dan lambat serta memperkenalkan jenis gending kaitannya dalam mendukung suasana garapan tari, seperti misalnya pada garap gending di Jawa dikenal ada gending ketawang, lancaran, dan ladrang. Dari pola gending tersebut menunjukkan bahwa gending ketawang menggunakan tempo lambat sedangkan lancaran menggunakan tempo cepat. Ini sangat membantu penari jika diberikan sejak awal dengan demikian rasa musikal akan tumbuh dalam jiwa penari. Kedua kebanyakan dari mahasiswa meminta bantuan orang lain (yang menguasai karawitan/musik) untuk membuatkan musik karya tarinya. Ini sangat dimungkinkan karena penciptaan gending-gending dalam tari membutuhkan disiplin ilmu yang khusus. Secara umum tidak semua penata tari terutama mahasiswa yang perempuan memiliki kemampuan dalam bidang musik /karawitan.

\section{PENUTUP}

Berdasarkan hasil penelitian dan pembahasan di atas dapat disimpulkan sebagai berikut: a) Mahasiswa mengalami kesulitan dalam menciptakan karya tari. b) Data yang diperoleh menunjukkan tingkat kesulitan yang dialami mahasiswa sebagai berikut: cerita 2,08\%, tema 2,22\%, busana 2,26\%, gerak 2,46\%, dan musik 3,10\%. Dari rerata skor ini ditemukan bahwa tingkat kesulitan yang paling tinggi terletak pada cerita.

Untuk mengantisipasi dari temuan tersebut di atas, mengingat matakuliah koreografi III adalah mata kulliah yang berjenjang maka pada jenjang sebelumnya perlu dikaji lebih banyak materi pembelajaran yang berkaitan dengan cerita dan tema. Sementara itu, untuk busana perlu penekanan pada materi dalam mata kuliah tata busana lebih banyak diberikan tentang busana tradisi khususnya yang berkaitan dengan tari. Di samping itu perlu meningkatkan proses pembelajaran persiapan dosen dan mahasiswa dengan mengembangkan media pembelajarn yang berkaitan dengan cerita, tema, dan busana, mengkaji lebih banyak pada mata kuliah sebelumnya yaitu pada mata kuliah koreografi I dan II. Dengan demikian mahasiswa akan lebih siap ketika menghadapi penciptaan tari 
pada kelas koreografi III. Kedua Meningkatkan apresiasi mahasiswa dengan menyaksikan pertunjukan secara langsung baik karya tari tradisi maupun yang modern.

\section{DAFTAR PUSTAKA}

Meri, L. 1975. Komposisi Tari Elemen-elemen Dasar. Yogyakarta: ASTI.

Hidayat, Robby. 2011. Koreografi \& Kreativitas Pengetahuan dan Petunjuk Pratikum Koreografi.Yogyakarta: Kendil Media Pustaka Seni Indonesia.

Jacqueline, Smith. 1985. Komposisi Tari, Sebuah Petunjuk Praktis BagiGuru. Yogyakarta: I KALASTI.

Hadi, Sumandiyo. 2003. Aspek-aspek Dasar Koreografi Kelompok. Yogyakarta: LKAPHI. . 2011. Koreografi( Bentuk,Teknik, Isi). Yogyakarta: Cipta Media.

Sugiyono. 2012. Metode Penelitian Kuantitatif, Kualitatif, dan R\&D. Bandung: Alfabeta.

Sugihartono,dkk. 2012. Psikologi Pendidikan. Yogyakarta: UNY Press.

Primadi, Tabrani. 2000. Proses Kreasi, Apresiasi, Belajar. Bandung: ITB 